Prawo Kanoniczne

57 (2014) nr 4

O. DARIUSZ BOREK, O. CARM.

\title{
THE CANONICAL DELICTS LIABLE TO PENAL SANCTIONS RESERVED TO THE APOSTOLIC SEE
}

Summary: Introduction. - 1. Profanation of consecrated species. - 1.1. Essential features of a delict. -1.2 . Penal sanctions. -1.3 . Indications regarding request for remission of penalty. -2 . Physical assault upon the Roman Pontiff. - 2.1. Essential features of a delict. - 2.2. Penal sanctions. - 2.3. Indications regarding request for remission of penalty. - 3. Absolution of an accomplice in a sin against the sixth commandment of the Decalogue. - 3.1. Essential features of a delict. 3.2. Penal sanctions. - 3.3. Indications regarding request for remission of penalty. 4. Consecration of a bishop without a pontifical mandate. - 4.1. Essential features of a delict. - 4.2. Penal sanctions. - 4.3. Indications regarding request for remission of penalty. -5 . Direct violation of sacramental seal. -5.1 . Essential features of a delict. -5.2 . Penal sanctions. -5.3 . Indications regarding request for remission of penalty. 6 . An attempt to ordain a woman to the priesthood. -6.1. Essential features of a delict. -6.2 . Penal sanctions. -6.3 . Indications regarding request for remission of penalty.

\section{Introduction}

Amongst various forms of cessation of penalties within the Church law it is remission which is of significant importance, be the subject of eight out of nine canons. Its priority is connected with a peculiar role of the institution dealing with exemption from penalties, as largely proved in the course of history and canonical practice ${ }^{1}$. And this special legal faculty derives from the very nature of cessation of penalty in effect of remission. It is invariably the act of administrative body which is necessary to exempt the faithful from the penalties of excommunication, interdict or suspension. This singular aspect of cessations of ecclesiastical penalties is closely associated with the redemptory aim

\footnotetext{
1 A. Borras, Les sanctions danas l'Église, Paris 1990, 125.
} 
of censures to be imposed on an offender until his reformation (can. $1358 \S 1$ ). Therefore, the remission is the cessation of penalty upon the intervention of a competent authority, empowered to exempt from medicinal penalties (censures) or dispenses from expiatory penalties. An exemption thus refers to censures and is the act of justice, always conducted $a b$ homine, whereas a dispense refers to expiatory penalties and is the act of mercy through which an offender is released from serving an expiatory penalty before its term elapses (it is also possible to exempt from an expiatory penalty by a competent superior).

According to the currently applicable canon law it is exclusively the Apostolic See which has the power herself or can empower another subject to remit penalties. This reservation of power to exempt from penalties is possible only at the moment of adjudging a sentence, whether in a decree or order ${ }^{2}$. It should be noted that the sentences adjudged by the Holy See in her penal orders are also strictly reserved. It is absolutely impossible to reserve penalties in the course of trial, and the penalty which has not been strictly reserved before, cannot become such at the moment of its pronouncement or imposition. Considering the dispositions included in cann. $1355 \S 1$ and $1356 \S 1$, and the requirement of closest interpretation as specified in can. $1354 \S 3$, it should be acknowledged that a reservation clause in a judgment or decree, regarding pronouncement or imposition of a penalty, must not be inserted.

Whether reservation has a penal or civil nature is a widely discussed problem of the doctrine of the canon penal law. Some experts claim that the basis of reservation is not penalty itself but maintaining public good and church discipline. Others infer, besides public good, the penal aspect of it. In its strict meaning, reservation is definitely not a penalty, nor does it increase penalty prescribed in a legal act, although it may impede the proceedings towards penalty remission. From the delinquent's perspective it is far more difficult for him to receive exemption from a penalty reserved by the Apostolic See than from an unreserved one. It should be assumed that reservation is a kind of ad-

${ }^{2}$ Cf. CIC/1983, cann. $1355 \S 1,2$ and $1356 \S 1$. 
ministrative regulation rather than penal law in view of the fact that it does not produce any circumstances inhibiting sanity (e.g. ignorance ${ }^{3}$.

The Code of Canon Law from 1983 prescribes reservation of penalties by the Apostolic See with regard to serious delicts in exceptional cases. In the third paragraph of can. 1354 there is a reference to the regulation stated in can. 18, namely the provision of strict interpretation of reservation. Wherefore, reservation must always be clearly provided by law and not based on presumption. If there is doubt, legal or factual, reservation of penalty does not apply (can. 14).

With respect to the penalties reserved to the Apostolic See which may be remitted, there should be a clear distinction between internal and external exemptions from penalties. In the case of internal remissions the competent authority remains the Apostolic Penitentiary ${ }^{4}$. As regards external remissions, the right to exempt from the penalties reserved to the Apostolic See belongs to the Congregation for the Doctrine of Faith ${ }^{5}$. The standard procedure of penalty remission is the external one. However, due to pastoral reasons the Code of Canon Law provides the precepts for internal remission of penalties. The latter form of remission is prior to the external or even independent from the external one. Thus it may be concluded that internal remission of penalties should not be a rule, but rather an exception to it.

The aim of this paper is to analyze the delicts which are subject to excommunication latae sententiae, the exemption from which is reserved to the Apostolic See. To examine these offences it seemed necessary to pay particular attention to the essential features of them, penal sanctions and indications regarding requests for remission.

${ }^{3}$ Por. J. Syryuczyk, Sankcje w Kościele. Część ogólna. Komentarz, Warszawa 2008, 295-296.

${ }^{4}$ CIC/1983) can. 64; Joannes Paulus II, Constitutio Apostolica de Romana Curia Pastor Bonus, 28 iunii 1988, AAS 80(1983), 841-930, art. 117, 118.

5 Cf. Joannes Paulus II, Constitutio Apostolica de Romana Curia ..., art. 52; A. CALABrese, Diritto penale canonico, Città del Vaticano 1996, 237. 


\section{Profanation of consecrated species}

The very first delict which the Code of Canon Law of 1983 reserved to the Apostolic See is the offence specified in can. 1367: "A person who throws away the consecrated species or takes or retains them for a sacrilegious purpose incurs a latae sententiae excommunication reserved to the Apostolic See; moreover, a cleric can be punished with another penalty, not excluding dismissal from the clerical state". It is the delict consisting in taking or reserving the consecrated species for sacrilegious purposes, or disposing of them, also for sacrilegious purposes, although the latter is not clearly stated in the canon.

The offence of profanation of consecrated species is classified among the delicts to be examined, persecuted and punished exclusively by the Congregation for the Doctrine of Faith, both pursuant to Norms De gravioribus delictis from $2001^{7}$ and De delictis reservatis from $2010^{8}$.

\subsection{Essential features of a delict}

When scrutinizing the offence of profanation of consecrated species we need to remember that in order to charge with this offence, the forbidden actions must concern the consecrated species for only in them does the Catholic faith recognize a factual, real and substantiated presence of the Body and Blood of Jesus Christ. The species are regarded as consecrated if they are placed in a tabernacle or they are adored by or given out to the faithful. However, anyone who profanes

${ }^{6}$ CIC/1983, can. 1367; CCEO (1990), can. 1442.

${ }^{7}$ Congregatio pro Doctrina Fidei, Epistula a Congregatione pro Doctrina Fidei missa ad totius Catholicae Ecclesiae Episcopos aliosquae Ordinarios et Hierarchos interesse habentes: de delictis gravioribus eidem Congregationi pro Doctrina Fidei reservatis, 18 maii 2001, AAS 93(2001), 785-788.

${ }^{8}$ Congregatio pro Doctrina Fidei, Normae de delictis Congregationi pro Doctrina Fidei reservatis seu Normae de delictis contra fidem necnon de gravioribus delictis (21.05.2010), AAS 102(2010), 419-434. See also: Congregazione PER LA DotTrina Della Fede, Modificate Le norme „,de gravioribus delictus”: procedure più efficaci per contribuire alla cogóiarezza del diritto, L'Osservatore Romano, 16 luglio 2010, 1, 4-5, 8 . 
a species not yet consecrated, believing it to be such, commits a sin but not an offence. The object profaned may be of both species, that is, bread and wine, although it should be remembered that an offence is committed even if only one consecrated species has been profaned. The object legally protected is every part and the whole of consecrated species of bread and wine. The cited delict does not pertain to direct celebration of the Sacrament of Eucharist, during which Christ's Sacrifice is re-enacted, but to "consecrated species". In order to pronounce an offence we shall deal with species validly consecrated or else there would not be an offence but rather a sin committed by a person who intended to profane a consecrated species. To state an offence it is not necessary that a person should believe in the Sacrament of Eucharist (however, it should always be a Catholic - cf. can. 1, can. 11, can. 1311). It is enough that a person knows that he deals with bread and wine, factually consecrated by the rites and doctrine of the Catholic Church. Moreover, an offence is pronounced if the above mentioned actions have been carried out with intention of profanation.

The delict of profanation of consecrated species is classified into: taking (abductio), retaining (retentio) and abandoning (abiectio).

The first form of profanation of consecrated species, as described in can. 1367, is abduction - taking consecrated species. To take a consecrated species is to gather it from a place it is normally kept and put in another, unadjusted place even if not dirty or improper. The entire activity must be conducted with a sacrilegious purpose as the very idea of this offence is not merely to take away consecrated species from the ritually adjusted place, but to take them in order to profane ${ }^{9}$. The purpose is defined as sacrilegious when consecrated species become an object of insolent and unholy act, of black mass celebrations, satanic or masonic rites, magical practices, divination and other superstitions. A sacrilegious purpose is presumed in the event a person who has simulated the receipt of the Holy Communion, yet takes It out from his mouth and retains in order to throw away into a dustbin or another un-

\footnotetext{
${ }^{9}$ Cf. J. SyryjCzyK, Kanoniczne prawo karne, część szczegółowa, Warszawa 2003,
} 50 . 
clean, foul place, onto the ground or into fire or water ${ }^{10}$. An offence is not committed by someone who after receiving the Holy Communion, takes out the host and for pious purposes retains It in their prayer book, although he commits a grave sin, as expressly forbidden by the canon law ${ }^{11}$. Certainly it is not an offence if consecrated species are taken by a secular in order to save from fire or profanation, which is not a sacrilegious act but rather a praiseworthy deed. The more so if the above action is carried out by a cleric, deacon or another person entitled to give out the Holy Communion, and in the case of clerics and deacons it is their obligation ${ }^{12}$.

The second form of profanation of consecrated species is retention - retaining consecrated species. The Congregation for Divine Worship and the Discipline of the Sacraments in its Instruction of 25 march 2004 reminded of the obligation of storing the Most Holy Sacrament in a tabernacle, pursuant to all the prescriptions of the liturgical books and to the norms of law, especially as regards the prevention from the danger of profanation. Wherefore, it is forbidden to reserve the Blessed Sacrament in a place where there is a danger of profanation ${ }^{13}$. We can assume that a person reserving the consecrated species in a place endangered by profanation is the one who stores It, for instance, in a pocket, bag, as well as at his house or in a another inappropriate place. Yet, so as to pronounce an offence, reserving the consecrated species must be made with a sacrilegious purposes. That is why not every storage of consecrated species beyond properly adjusted places shall be an offence. For example, a cleric carrying a burse with consecrated species while walking outside church, going by bus or simply travelling, always ready to administer the viaticum if necessary, certainly does not reserve consecrated species with sacrilegious purposes, and hence does not commit an offence, although such practice is forbidden

${ }^{10}$ A. Calabrese, Diritto penale ..., 272-273.

${ }^{11}$ CIC/1983, can. 935.

${ }^{12}$ Cf. R. BотtA, La norma penale nel dritto della Chiesa, Bologna 2001, 178-179.

${ }^{13}$ The Congregation for Divine Worship and the Discipline of the Sacraments, Instruction, On certain matters to be observed or to be avoided regarding the Most Holy Eucharist, 130-131, (Kraków 2004), 71-72. 
unless pastoral necessity urges it as stated in can. 935 of the CIC/1983. Similarly, it is not an offence when a person keeps consecrated species at home out of wrongly understood piety ${ }^{14}$. The delict of retaining consecrated species is closely linked with the above presented offence of taking them. Therefore the delinquent who committed an offence of reserving consecrated species may be the one who took them before, for instance when receiving the Holy Communion without consuming It. And thus the question arises whether a person who has taken consecrated species and then reserves them with sacrilegious purposes commits two or only one offence. Most probably, it is one offence for these two acts may be regarded as one, since taking the Holy Eucharist involves reserving It, although storing might last for a longer period of time. As rightly observed by J. Syryjczyk, the aim of legislature is to emphasize the punishability of various subjects of offence, as indeed, it might be two different persons who take consecrated species and retain them ${ }^{15}$. This problem evokes various opinions ${ }^{16}$. In practice, it may be assumed that if the same person takes and reserves consecrated species it should be regarded as one offence, albeit of bigger gravity ${ }^{17}$.

The third form of profanation of consecrated species is abiectio - abandoning them. The abandoning (Latin. abiectio from abicere abandon), interpreted in its broadest sense, as prescribed by the Pontifical Council for the Interpretation of Legislative Texts, denotes voluntary and greatly contemptuous act towards consecrated species $^{18}$.

\footnotetext{
${ }^{14}$ Cf. A. Calabrese, Diritto penale..., 273.

${ }^{15}$ J. SyryjCZyK, Profanacja Eucharystii wedtug karnego ustawodawstwa kanonicznego i polskiego prawa karnego, Prawo Kanoniczne 29(1986) nr 3-4, 197-198.

${ }^{16} \mathrm{Cf}$. The opinions that a person who has taken and retained consecrated species commits one offence are the following: A.G. URRU, Punire per salvare. Il sistema penale nella chiesa, Roma 2002, 198; A. CAlABrese, Diritto penale ..., 274; J. Syry JCZyK, Kanoniczne prawo karne..., 50-51. The contrary opinions are shared by: R. BotTA, La norma penale..., 179.

${ }^{17}$ Cf. A. Calabrese, Diritto penale..., 274.

18 "Patres Pontificii Consilii de Legum Textibus Interpretandis, in plenario coetu diei 4 iunii 1999, dubio, quod sequitur, respondendum esse censuerunt ut infra: D. Utrum in can. $1367 \mathrm{CIC}$ et $1442 \mathrm{CCEO}$ verbum < abicere > intelligatur tantum ut actus proiciendi necne: R. Negative et ad mentem. Mens est quamlibet actionem Sacras Species voluntarie et graviter despicientem censendam esse inclusam in verbo <abicere>",
} 
Wherefore, abandoning consecrated species should be understood as throwing them away or throwing onto the ground, into fire, rubbish tip, latrine or another dirty place, out of contempt, disrespect, malice, hatred towards God or out of any other reason. Abandoning also denotes treading on consecrated species, expectorating on the Holy Host after receiving It, as well as expectorating on consecrated species, throwing manure or wastes onto them or shooting to them ${ }^{19}$. Furthermore, the expression „quamlibet actionem Sacras Species voluntarie et graviter despicientem" should also include the situations when the Holy Sacrament, presented for adoration, becomes an object of insult and profanity $^{20}$. Obviously, the above described acts are presumed as malicious and sacrilegious. Yet profanation does not take place if a thief who steals a pyx with consecrated species, has first put hosts on the altar or tabernacle, that is, in proper and consecrated places for storing. However, if a thief while stealing a precious chalice, spills onto the ground or some other improper place consecrated wine, commits the offence of profanation. The offence might be avoided if he poured wine into another container, e.g. a glass and put it on an altar ${ }^{21}$.

The case of profanation of consecrated species must involve so called specific dolus, occurring when besides general dolus ${ }^{22}$, there

Pontificium Consilium de Legum Textibus Interpretandis, Responsio ad propositum dubium, 4 iunii 1999, Communicationes 31/1 (1999), 38.

${ }^{19}$ The described actions had not been regarded as acts of profanation of the Most Holy Sacrament according to the close interpretation of word ,abandon”, but until 1999 had been classified as delicts of profanation pursuant to can. $1376 \mathrm{CIC} / 1983$, cf. J. SyRYJCZYK, Kanoniczne prawo karne..., 49.

${ }^{20}$ Pontificium Consilium de Legum Textibus Interpretandis, Tutela della Sanctissima Eucaristia, Communicationes 31/1 (1999), 40. See also: D. Ciтo, Delicta graviora contro la fede e sacramenti, in: Questioni attuali di diritto penale canonico, Studi Giuridici XCVI, Città del Vaticano 2012, 40.

${ }^{21}$ The described case of spilling consecrated wine is rather hypothetical as the wine consumed during the Eucharist oblation is consecrated and such an offence can hardly occur. However, it might happen that a priest co-celebrating the Holy Mass or a secular participating in celebration, receiving the Chalice with the Blood of Christ, or seculars drinking the consecrated wine, might spill It onto the ground.

${ }^{22}$ General dolus occurs when there is only an ordinary intent of violating the law which is sufficient to pronounce an offence while motivation and purpose are not im- 
is a specific intent, special motivation of a delinquent to commit an offence. It should be noted that if a particular delict requires specific dolus as a constitutive element, this offence is regarded as accomplished irrespective of an intent realized or not. And on the contrary, a delict is not regarded as such if a purpose required for an offence to be pronounced is not present in an intent nor projected by an offender. For this instance, the offence of profanation of consecrated species is, according to can. 1367 an offence with a specific purpose, that is, it requiring deliberate specific guilt: abandoning, taking and reserving of consecrated species must be committed in sacrilegum finem. Therefore, if a delinquent takes away consecrated species with a purpose of profanation, but does not finally accomplish this act, a deliberate specific guilt has occurred, and consequently, sanity of actions. Yet, if a person takes away consecrated species without intent of profaning them (no in sacrilegum finem action), nor planning such an act or even not considering it (taking the Host home out of pious reasons - to adore It), does not commit an offence. In the latter case there is no required intention of committing a delict, although undoubtedly it is morally disapprovable.

\subsection{Penal sanctions}

For a delict of profanation of consecrated species the Code of Canon Law, can. 1367, prescribes the penalty for everybody who have committed this offence and, additionally, another penalty may be imposed upon a cleric who has committed this offence.

Pursuant to canon 1367 a delinquent who has committed the offence of profanation of consecrated species is incurred with the penalty of excommunication, reserved to the Apostolic See. This penalty is imposed in both cases of adisclosed and undisclosed offence. It is the frequent or even always the case of an undisclosed offence. It remains such even if more than one person has participated in profanation. The pronouncement of penalty will be necessary if a censure is to be laid upon an offender on the external forum. The remission of the penalty

portant, as in the case of e.g. can. $1370 \S 1$ - physical assault upon the Roman Pontiff. 
of excommunication may be granted exclusively by the Apostolic Penitentiary within the internal scope and the Congregation for the Doctrine of Faith within the external scope ${ }^{23}$. Additionally, it may be granted by any cleric within the internal, sacramental scope in the event the life of an offender is in danger ${ }^{24}$, yet a delinquent is obligated to appeal to the competent authority after his recovery or when no longer being in a life-threatening situation ${ }^{25}$.

The particular references can be found in can. 1367 regarding clerics, namely, deacons, presbyters and bishops ${ }^{26}$. Besides the penalty of excommunication latae sententiae, they may be punished with other penalties, not excluding dismissal from the clerical state. The profanation of consecrated species committed by a cleric is a very serious offence

On the other hand, it is practically impossible for any cleric, a priest in particular, to commit such a delict. A priest is a dispenser of the Eucharist in its broadest sense: celebrates It, distributes, delivers to the sick, stores and protects from endangerment and profanation. Therefore, whereas in the case of a lay person, taking and reserving consecrated species may be presumed as made for sacrilegious purposes, this presumption is hardly considered in the case of a cleric due to his numerous pastoral duties and services related to the Most Holy Eucharist. Finally, it should be emphasized that all additional penalties to be incurred upon clerics are optional, depending on a considerate decision of a an ordinary or judge ${ }^{27}$.

\subsection{Indications regarding the remission of penalty}

The request to the Apostolic See, as regards the delict of profanation of consecrated species, should include the following data: age (at least approximate) of a penitent and his mental health report; date of

${ }^{23}$ Joannes Paulus II, Constitutio Apostolica de Romana Curia..., art. 52, 117, 118.

${ }^{24}$ CIC/1983, can. 976.

${ }^{25} \mathrm{CIC} / 1983$, can. $1357 \S 3$.

${ }^{26}$ Cf. CIC/1983, cann. 1009, $266 \S 1$.

${ }^{27}$ See: Z. Suchecki, Le sanzioni nella Chiesa. Parte I. I delitti e le sanzioni penali in genere (cann. 1311-1363), Città del Vaticano 1999, 139-140. 
committing an offence; number of offences (how frequent?); manner of committing an offence (in what way?); motifs which made a penitent commit the offence of profanation of consecrated species (e.g. hatred or revenge towards God; material benefits); was the offence committed by a penitent alone or did he assist other persons in it (were persons implicated clerics or monastics); did a penitent commit an offence inspired or encouraged by a sect and has he broken off any contact with them (would he be ready, while still belonging to the sect, to inform a diocesan bishop of the committed profanations. It is necessary for securing common good and can only be made with penitent's consent, with respect for his confidentiality right and through the intermediary of a confessor); does a penitent show indispensable signs of conversion and remorse for the committed sin; can a penitent be trusted and is in good mental health ${ }^{28}$.

The questions of crucial importance in dealing with a request are: why, how and how often. Thus it is essential to establish whether a delict has been committed out of antagonism towards God, or out of other reasons, such as, money or encouragement by other members of a sect. Was an offence committed in secret or in front of other persons, were there any clerics or monastics present) ${ }^{29}$.

\section{Physical assault upon the Roman Pontiff}

The second delict reserved by the Code of Canon Law of 1983 to the Apostolic See is the offence stipulated under can. 1370 §1: "Who uses physical force against the Roman Pontiff incurs a latae sententiae excommunication reserved to the Apostolic See; if he is a cleric, another penalty, not excluding dismissal from the clerical state, can be added according to the gravity of the delict" ${ }^{\prime 30}$. The quoted prescription pertains to the offence of physical assault upon the Pope which is clas-

${ }^{28}$ C.E. Commentz, Quando e come ricorrere alla Penitenzieria Apostolica, Città del Vaticano 2011, 20-21.

${ }^{29}$ Paenitentiaria Apostolica, Lettera pro memoria, 24.10.1983, in: Canon Law Digest, vol. 11, 49-52; see also: W.H. Woestmen, Ecclesiastical sanctions and the Penal Process. A Commentary on the Code of Canon Law, Ottawa 2000, 261.

${ }^{30} \mathrm{CIC} / 1983$, can. $1370 \S 1$. 
sified among the delicts committed against the Church authorities with a view to protecting the office and authority of the Supreme Pontiff of the Church.

\subsection{Essential features of the delict}

Using physical force against the Pope is a particularly serious offence. The Roman Pontiff holds the most supreme, complete, immediate, and universal power in the Church, which he is, always and everywhere, able to exercise without restraint (can. 331). The Pope is the head of the highest authority and at the same time the fundament of unity of the entire Church community. The physical assault upon His Holiness is tantamount to the assault upon the ultimate authority of the Representative of Christ on earth. This delict usually causes common depravation, especially when committed by a cleric.

Applying physical force against the Pope can be regarded as the delict of can. $1370 \S 1$ if it is: 1 - external; 2 - violent; 3 - directed against a person; 4 - unjustified. Firstly, the prohibited actions must be of an external nature, which means that they must be physical, not verbal. Secondly, they must be violent, that is, against a victim's will or else the rule of volenti non sit iniuria might be applied. Thirdly, the prohibited actions must be directed against a person: either against his bodily integrity or his civil liberty, or his dignity. Bodily integrity is violated by: physical injury, murder, battery, knock-out, stone-throwing, etc. Civil liberty in infringed by detention, confinement, banishment or kidnapping. The Pope's dignity is infringed by expectoration, shoves, muck or paint throwing, pushing into water or tearing garments. All the above cases of delicts against the Pope consist in actions against the integrity of a physical person and not against his good name or material possessions. Lastly, the fourth feature of the physical assault upon the Roman Pontiff is lack of its justification. Therefore there is no punishable offence in the event the physical force has been applied as vim vi repellere licet, that is, in self defence. 


\subsection{Penal sanctions}

The delict scrutinized above is punished with latae sententiae excommunication reserved to the Apostolic See for the reserved penalty must be strictly interpreted (can. 1354 §3). If the offence has been committed by a cleric (deacon, presbyter, bishop), the judge may, besides excommunication, impose another penalty (facultative right) not excluding dismissal from the clerical state.

A monastic who has committed the delict of assault upon the Pope is also to be dismissed from his institute (cann. 695, 1397).

\subsection{Indication regarding request for remission of penalty}

Due to the fact that in order to commit the above delict all elements must be included, both subjective and objective, it seems practically improbable that such an offence might be pronounced ${ }^{31}$.

Nonetheless, if such an offence occurs, a request for exemption addressed to the Apostolic See must include the following data: age (at least approximate) of a penitent and his mental health report; date of committing an offence; number of offences (how frequent?); manner of committing an offence (in what way?); motifs which made a penitent commit the offence of physical assault upon the Roman Pontiff; was the offence committed by a penitent alone or did he assist other persons in it; did a penitent commit an offence inspired or encouraged by a sect and has he broken up any contact with them.

\section{Absolution of an accomplice in a sin against the sixth commandment of the Decalogue}

The third delict reserved by the Code of Canon Law of 1983 to the Apostolic See is the offence stipulated under can. $1378 \S 1$, pursuant to which: "A priest who acts against the prescript of can. 977 incurs a latae sententiae excommunication reserved to the Apostolic See"32 whereas according to can. 977: "The absolution of an accomplice in a

\footnotetext{
${ }^{31}$ Cf. C.E. Commentz, Quando e come ricorrere..., 13.

${ }^{32} \mathrm{CIC} / 1983$, can. $1378 \S 1$.
} 
sin against the sixth commandment of the Decalogue is invalid except in danger of death". ${ }^{33}$ The delict reserved thus pertains to one offence related to the Sacrament of Penance, namely, absolution of an accomplice in a sin against the sixth commandment of the Decalogue.

The above kind of absolution belongs also to the category of the offences, the examination of which, pronouncement or imposition of penalty, are reserved to the Congregation for the Doctrine of Faith both by Norms De gravioribus delictis from $2001^{34}$ and De delictis reservatis from $2010^{35}$.

\subsection{Essential features of a delict}

So as to pronounce the delict of absolution of an accomplice in a sin against the sixth commandment of the Decalogue three elements are required: firstly - mortal sin against the sixth commandment of the Decalogue; secondly - relation based on cooperation in a sin between a priest-confessor and a priest-absolver; thirdly - actual absolution of the above sin, that is, recitation of the absolution formula by a confessor.

Canon 977 forbids the absolution of an accomplice, under pain of nullity, only in the case of a mortal sin against the sixth commandment of the Decalogue. Therefore, other sins, even the most severe ones but not related to the sixth commandment of the Decalogue are not considered here. It should be emphasized that it is not any sin of the sixth commandment but only the mortal one. Thus all the cases in which at least one party, out of various reasons, such as, mental condition, has not committed a mortal sin, should be excluded ${ }^{36}$. Pursuant to can. 1321 $\S 1$ of CIC/1983 no one is to punished unless the external violation of a law or precept has been committed. Consequently, in the discussed case of a mortal sin against the sixth commandment of the Decalogue

${ }^{33}$ CIC/1983, can. 977.

${ }^{34}$ Congregatio pro Doctrina Fidei, Epistula ..., 785-788.

${ }^{35}$ Congregatio pro Doctrina Fidei, Normae de delictis..., 419-434.

${ }^{36}$ Cf. G.P. Montins, La tutela del sacramento della penitenza. I delitti nella celebrazione del sacramento (cann. 1378; 1387; 1388), in: Le sanzioni nella Chiesa, red. Gruppo Italiano Docenti di Diritto Canonico, Milano 1997, 219. 
there may occur both kinds of violation, external and internal taking different forms ${ }^{37}$. The Catechism of the Catholic Church teaches that the tradition of the Church has understood the sixth commandment as encompassing the entire human sexuality ${ }^{38}$.

Complicity denotes that there are at least two persons, although there may be more, who consciously and voluntarily participate in the same sin. An accomplice is any person who agrees to commit a sin together. Without his consent there is no complicity ${ }^{39}$. Therefore the mortal sin against the sixth commandment of the Decalogue must be committed by all persons involved, not only by a confessor. An accomplice may be a person who was able to commit a mortal sin or who has actually committed such a sin with a confessor ${ }^{40}$.The time, that is, the moment of committing a sin is not relevant here. Thus it is unimportant whether at the moment of committing a mortal sin against the sixth commandment a priest was ordained or whether he assisted in the offence long before taking holy orders ${ }^{41}$.

However, the delict is deemed as committed only at the moment of reciting by a confessor the formula of absolution with intention of granting $\mathrm{it}^{42}$. It should be noticed that according to $1378 \S 1$, the delict itself consists in invalidly given absolution. It is important due to the fact that there may be situations when a confessor grants absolution of a sin against the sixth commandment committed by an accomplice most validly, such as in the danger of death. In this situation a confessor retains his authority to absolve. Furthermore, the interdiction of ca. 977 pertains only to the sins which have not been absolved yet, so there is not offence if an accomplice has already been absolved of the $\sin ^{43}$. It

${ }^{37}$ Cf. A. Calabrese, Diritto penale..., 299.

${ }^{38}$ Cf. CCC, n. 2336.

${ }^{39}$ If there is no such a consent, other offences might be considered, according to can. 1395, cf. P. BARBERO, Tutela della comunione ecclesiale e sanzioni canoniche, Lugano 2011, 207.

${ }^{40}$ Cf. J. SyryJCZYK, Kanoniczne prawo karne..., 97-98.

${ }^{41}$ Cf. G.P. Montini, La tutela del sacramento della penitenza ..., 218-219.

${ }^{42}$ Cf. J. SyryjczyK, Kanoniczne prawo karne..., 98.

${ }^{43} \mathrm{Cf}$. Communicationes 15(1983), 210. 
should also be observed that, according to can. $1321 \S 2 \mathrm{CIC} / 1983$, so as to pronounce a delict a confessor must act deliberately, violating the interdiction of cann. $1378 \S 1$ and 977, for a person who has infringed the law due to priestly negligence does not icur a penalty. Accordingly, a confessor must realize that he attempts to absolve his accomplice in a sin against the sixth commandment of the Decalogue and that such absolution is forbidden, and that he grants absolution unlawfully ${ }^{44}$.

\subsection{Penal sanctions}

Prescripts 977 and $1378 \S 1$ of the Canon law have been drawn in order to protect the Sacrament of Penance. Giving absolution to an accomplice of a sin against the sixth commandment of the Decalogue is an abuse of absolutory power. In the natural law a crime associate should not judge and resolve an accomplice of a mutually committed offence. Such a situation produces, as well, a moral dilemma for an offender concerning his spiritual conversion, which in effect discourages him from abandoning a sin. There is also the question of depravation of the congregation leading to disregard of Christian morality, the abuse of the sanctity of the Sacrament of Penance and insult to the Church. Finally, an argument for the punishability of this delict is general prevention, that is, an educational role of a penal sanction.

A confessor who absolves his accomplice of a sin against the sixth commandment of the Decalogue incurs a latae sententiae excommunication reserved to the Apostolic See. And it should be noticed as well that, according to can. 977, absolution granted to an accomplice of a sin against the sixth commandment of the Decalogue is invalid except in danger of death.

\subsection{Indications regarding request for remission of penalty}

Due to the confidential nature of this delict, it is rather the Congregation for the Doctrine of Faith which examines the case. A request for

${ }^{44}$ Cf. G.P. Montini, La tutela del sacramento della penitenza ..., 220. 
remission of penalty of latae sententiae excommunication should be addressed to the Apostolic Penitentiary ${ }^{45}$.

The request for exemption from the penalty with regard to the delict of absolution of an accomplice in a sin against the sixth commandment of the Decalogue, addressed to the Apostolic See, should include the following data: age (at least approximate) of a penitent, namely, a priest who has given absolution to his accomplice in a sin against the sixth commandment of the Decalogue; age (at least approximate) of an accomplice in a sin against the sixth commandment of the Decalogue who was granted the absolution by a priest-accomplice; sex of an accomplice; canonical status of an accomplice (not married, married, monastic, cleric); has it been the first of such absolutions; how many times such an invalid absolution has been granted; when was the last such an absolution was granted; has an offender broke off his sinful relations with an accomplice; has he changed his residential address or does he still live in the same place (vital due to the risk of re-committing a sin and an offence); does a penitent still hold the priesthood or not, is he a diocesan priest or a monastic, what positions does he hold, etc.; does a penitent live a life proper for the priestly state - does he perform daily Eucharist, does he pray the Liturgy of the Hours, etc. ${ }^{46}$.

An essential piece of information is the one whether an offence was a singularly, random event which took place during the time of some intense crisis, temptation or circumstance, in which a priest found himself. Or else there were more cases of granting absolution to an accomplice in a sin against the sixth commandment of the Decalogue, which might indicate specially mean and dogged persistence in continuing this sin. In such a case it is advisory to determine how often absolution was granted, how many accomplices were involved, if they were persons of male or female sex or both. Furthermore, with respect to severity of a delict, it is crucially important to establish the status of accomplices, whether they were monastics, married women or semina-

${ }^{45}$ Cf. D. Cito, Delicta graviora ..., 44. See: P. BArbero, Tutela della comunione..., 207-208.

${ }^{46}$ C.E. Commentz, Quando e come ricorrere..., 21-22. 
rians. All of this information may serve as incriminating circumstances if related to fornication, sacrilege and due to their tremendous spiritual harmfulness. It is also important to learn if a cleric has relinquished his sinful conduct and leads his life in accordance with his state. Moreover, whether he still holds priesthood, either as a diocesan priest or a monastic ${ }^{47}$.

Only when learning the answers to the above questions will the Penitentiary be able to resolve the matter properly and give a penitent necessary support to persevere in reformation and spiritual revival, and to undertake internal measures with a view to securing the sanctity of the Sacrament of Reconciliation and common good by protecting the faithful from depravation ${ }^{48}$.

\section{Consecration of a bishop without a pontifical mandate}

The fourth delict prescribed by the Code of Canon Law of 1983 as reserved to the Apostolic See is the offence specified in can. 1382, pursuant to which: "A bishop who consecrates someone a bishop without a pontifical mandate and the person who receives the consecration from him incur a latae sententiae excommunication reserved to the Apostolic See"49. Thus the prescript forbids ordination of a bishop if the consecration is to be made without a pontifical authorization.

\subsection{Essential features of a delict}

The essential features of the delict in question comprise: firstly lack of pontifical mandate; secondly - intentional guilt; thirdly - mutual participation in accomplishing an offence.

According to can. 1013 no bishop is allowed to consecrate anyone a bishop unless he is first assured that there is a pontifical directive. Whe-

\footnotetext{
${ }^{47}$ Paenitentiaria Apostolica, Lettera pro memoria, 24.10.1983, Canon Law Digest, vol. 11, 49-52; see also: W.H. Woestmen, Ecclesiastical sanctions ..., 261-262.

${ }^{48} \mathrm{D}$. Kos, Modo di fare i ricorsi e di accordarsi con il penitente, in: Tribunale della Penitenzieria Apostolica, Corso sul Foro Interno, 3-8 marzo 2008, Palazzo della Calcelleria, Roma.

${ }^{49} \mathrm{CIC} / 1983$, can. 1382.
} 
refore, it is not permitted to consecrate a bishop without prior ordinance or authorization from the Pope. The ordination conducted without a pontifical mandate is valid but despicable. This is important since can. 1013 regulation does not contain a nullifying clause, and pursuant to can. 10 the only nullifying precepts are those which expressly state that an act is invalid. Consecration of a bishop without a pontifical mandate is despicable for, according to the Divine Law, every bishop is to remain in the communion with the Pope and the College of Bishops. The pontifical mandate is thus a sign of staying in this hierarchical connection. Ordination of a bishop without the pontifical directive is an offence which in itself is an act of contumacy against the Bishop of Rome in the matter of highest priority; it is insubordination which, involving actual denial of the Roman primacy, is an act of schism ${ }^{50}$.

The very nature of the delict of can. 1382 requires that offenders have mutually agreed unlawful intent and participated together in accomplishing the act. Therefore, there must be dolus, that is, intentional guilt of both parties, a consecrator and the consecrated. Pursuant to can. 1382 the delict is thus committed by both, a bishop who illicitly ordains and a priest who gets ordained for both of them participate in the same offence despite their different roles. The legislative act of 1983 thus definitely prescribes the penal liability of both, a bishop ordaining without a pontifical mandate and of a priest receiving ordination. The legal problem arises when the consecration is conducted with participation of other bishops who are co-consecrators.

Pursuant to can. 1014, if the Apostolic See has not granted a dispensation, a bishop who is a principal consecrator, must take at least two other consecrating bishops to carry out ordination and it is highly appropriate that all the present bishops consecrate the elect together. The principal bishop, along with the other consecrating bishops carry out the act of consecration by laying their hands on the ordinand (the matter) and reciting the words of the consecration rite (the form). Hence the question arises: is a delict committed solely by the princi-

${ }^{50}$ John PaUl II, Motu proprio Ecclesia Dei (02.07.1988), AAS 82(1988), 14951498. 
pal consecrator or are all co-consecrating bishops implicated in this offence? (cf. can. 1329 \$2). In some fragment of the doctrine we find that the co-consecrating bishops are not indispensable participants of the delict as it may be accomplished without their involvement. Their presence is required rather for the sake of propriety, not validity. Thus, as the participants they do not have to be liable to latae sententiae excommunication. By this interpretation, all co-consecrating bishops might be punishable for involvement in an offence, but necessarily as accomplices. Wherefore, they may not be subject to latae sententiae excommunication imposed for illicit consecration of a bishop ${ }^{51}$, but such penalty might be incurred upon them optionally, depending on a considerate decision of a an ordinary or judge ${ }^{52}$. As rightly observed by $\mathrm{V}$. De Paolis, although all co-consecrating bishops may be regarded as actual consecrators and thus classified as accomplices to incur the same penalty as the main perpetrator, can. 1382 specifies about "A bishop, who...", so a singular grammar form is used. Accordingly, all possible co-consecrating bishops are not indispensable to commit an offence. Considering the rule of the closest interpretation of the penal prescripts, it should be concluded that can. 1382 does not scrutinize the case co-consecrating bishops as participants necessary to commit a delict ${ }^{53}$. The above interpretation is justifiable also in view of the

${ }^{51}$ Cf. A. CAlabrese, Diritto penale..., 310-311; J. SyryjczyK, Kanoniczne prawo karne..., 113-114; A.G. URRU, Punire per salvare..., 230; R. BotTA, La norma penale..., 210;

${ }^{52}$ Cf. J. Syry

${ }^{53}$ V. De Paolis, De Sanctionibus in Ecclesia. Adnotationes in Codicem: Liber VI, Romae 1986, 117. Calabrese, however, observes that co-consecrating bishops are not liable to ferendae sententiae penalties as pursuant to can. $1329 \S 1$ if a principal offender is sentenced to penalty, those who, upon common premeditated intent, participate in a delict (ferendae sententiae), and who are not expressly specified in a prescript or order, are liable to the same penalties or to other penalties of the same severity. It should be noticed that the scrutinized can. 1382 does not specify any ferendae sententiae penalties to be imposed on the principal offender, that is, in the said case on the principal consecrator. Accordingly, co-consecraters as well cannot incur ferendae sententiae penalties, A. Calabrese, Diritto penale ..., 311. Similarly, R. Botta, La norma penale..., 210, footnote $\mathrm{n}$. 248 . 
fact that the Congregation of Bishops, when declaring the penalties for illicit consecration of bishops by Archbishop Lefebvre, state that the Archbishop has incurred the penalty of excommunication of both, can. 1364 and 1382 for, respectively, the schism and for consecration of a bishop without pontifical mandate, whereas the co-consecrating bishop A. de Castro Mayer has been imposed with excommunication only for the delict of schism of can. $1364^{54}$.

Despite the above, the opinion derived from part of the doctrine, according to which co-consecrating bishops do not incur latae sententiae excommunication of can. 1382 as not being indispensable participants, is not fully acceptable. B.F. Pighin suggests a legal singularity of the case of co-consecrating bishops and that the perspective of indispensable participants is not adequate as in reality each of the co-consecrating bishops is de facto an actual dispenser of consecration with all its effects. The case is similar to the situation when several priests co-celebrate the Holy Mass, and as co-celebrants they all perform priestly service even if only one of the is the principal celebrant. Wherefore, according to B.F. Pighin, bishops who participate in illicit consecration of a bishop, as co-consecrators - are accomplices ${ }^{55}$.

Complicity, that is complete assistance or physical participation in an offence, is physical cooperation of several persons in accomplishing the same offence, with mutual intent of violating the law (delicti co-auctores). So as to pronounce complicity in an offence a few key conditions must be fulfilled. Firstly, mutual consent (communi consilio) of all co-offenders concerning the intent to commit an offence. Secondly, conscious physical cooperation in an illegal act ${ }^{56}$. Therefore, if on the part of the bishops, participating as co-consecrators in illicit ordination of a bishop, all the above mentioned conditions have been fulfilled, it may be assumed that they are liable to incur latae sententiae excom-

${ }^{54}$ Congregation of Bishops, Decree of 1 July 1988, (L'Osservatore Romano 03.07.1988), 1. 1. Also the decree of the Holy Office of 1951 did not incur excommunication, reserved specialissimo modo to the Apostolic See, upon co-consecrating bishops, see: S. Officio, Decreto Suprema Sacra, 9 aprile 1951, AAS 43(1951), 217-218.

${ }^{55}$ B.F. Pighin, Diritto penale canonico, Venezia 2008, 407.

${ }^{56}$ J. SyryjCZYK, Sankcje w Kościele..., 195. 
munication as being accomplices. Such a conclusion is justified by the declaration of 16 June 2011 issued by the Pontifical Council for the Interpretation of Legislative Texts, pertaining to a correct application of can. 1382 of the Code of Canon Law. It clearly specifies that all participants of ordination who serve as co-consecrators, that is, lay their hands and recite the words of the consecration prayer (cf. Caeremoniale Episcoporum nn. 582 and 584) are accomplices in a delict, thus equally liable to penalty ${ }^{57}$. According to the above declaration it is unquestionable that the delict prescribed in can. 1382 should be pronounced as such when committed by both, a bishop who unlawfully consecrates and by an ordinand bishop who is consecrated. Furthermore, the declaration of the Commission implies that also those who co-consecrate by laying their hands and reciting the consecration prayer should be regarded as accomplices in an offence and thus incur penalty.

\subsection{Penal sanctions}

Consecration of a bishop without a pontifical mandate and receiving holy orders to episcopacy without this mandate are subject to a penal sanction of can. 1382 in the form of latae sententiae excommunication, reserved to the Apostolic See. This penalty pertains to, first and foremost, a bishop ordaining to episcopacy and to an ordinand, that is, a consecrator and the consecrated ${ }^{58}$. As regards possible co-consecrating bishops it should be observed that all co-consecrating bishops as accomplices are liable to penalty of latae sententiae excommunication under can. 1382, unless any of them encounter personal circumstances which cause lack of sanity or which impede liability to latae sententiae penalties $^{59}$.

${ }^{57}$ Pontificio Consiglio Per i Testi Legislatvi, Dichiarazione sulla retta applicazione del canone 1382 del Codice di Diritto Canonico, 6 giugno 2011, (on the Vatican website).

${ }^{58}$ The examples of declarations see: S. Officio, Decreto Suprema Sacra, 9 aprile 1951, AAS 43(1951), 217-218; S.C. Per la Dottrina della Fede, Decreto Episcopi qui alios, 17 settembre 1976, AAS 68(1976), 623; S.C. PER LA DotTrina DELla Fede, Notificazione 12 marzo 1983, AAS 75(1983), 392-393.

${ }^{59}$ See: CIC/1983, cann. 1322; 1324. 
With respect to possible participants of illicit consecration of a bishop, the prescript of can. 1329 should apply, according to which they are liable to penalty depending whether they can be classified as principal offenders or as others, indispensable or not, participants of a delict.

4.3. Indications regarding request for remission of penalty

Due to the fact that in order to commit the above delict all conditions must be fulfilled, both subjective and objective, it seems practically improbable that such an offence might be pronounced. It is an offence which is of rather rare occurrence ${ }^{60}$.

\section{Direct violation of sacramental seal}

The fifth delict, reserved by virtue of the Code of Cano Law of 1983 to the Apostolic See is the offence of can. $1388 \S 1$, pursuant to which: "A confessor who directly violates the sacramental seal incurs a latae sententiae excommunication reserved to the Apostolic See; one who does so only indirectly is to be punished according to the gravity of the delict" ${ }^{\prime}$. This prescript implies one offence pertaining to the Sacrament of Penance, namely, direct infringement of confessional seal.

Direct violation of sacramental seal is also classified as the offences the examination of which, with pronouncement or imposition of penalty, is reserved to the Congregation for the Doctrine of Faith both by Norms De gravioribus delictis from $2001^{62}$, and De delictis reservatis from $2010^{63}$. However, it should be notified that according to the Norms of 2001 it is only direct violation of sacramental seal which is reserved to the above Congregation whereas the Norms of 2010 reserve both, direct and indirect violation of the sacramental seal to the Congregation.

\footnotetext{
${ }^{60}$ Cf. C.E. Commentz, Quando e come ricorrere..., 13.

${ }^{61} \mathrm{CIC} / 1983$, can. $1388 \S 1$.

${ }^{62}$ Congregatio pro Doctrina Fidei, Epistula..., 785-788.

${ }^{63}$ Congregatio pro Doctrina Fidei, Normae de delictis..., 419-434.
} 


\subsection{Essential features of a delict}

Canon 1388 consists of two paragraphs which specify two separate offences. Acordingly, the first paragraph, i.e. can. $1388 \S 1$ pertains to the delict against sacramental seal: confessarius qui sacramentale sigillum (...) violat. It refers to the duty of sigillum sacramentale which applies only to a confessor and a subject of confession (cf. can. 983). It is an absolute duty for it concerns the knowledge of the matters which a priest has learnt as a confessor, that is, in so called foro Dei. The second case, prescribed in can. $1388 \S 2$, specifies the offence against the secrecy of the subject of confession: interpretes aliiqui (...) qui secretum violat. A secret in question (secretum) referes to interpreters and all those who in certain ways have acquired information of the subject of confession. The quoted reservation of the Apostolic See, as regards exemption from penalty, pertains solely and exclusively to the violation of sigillum sacramentale of can. 1388 \$2.

Pursuant to the prescript of can. 983, a confessor is obligated to fulfill the two following duties. Firstly, to preserve in secrecy the sins about which he has learnt during confession. Secondly, not to use the knowledge acquired during confession even if there is no danger of spreading it. The above duties never allow exceptions, even due to the most serious reasons, thus no justifiable cause, such as necessity or grave inconvenience, can be approved ${ }^{64}$. Intelligibly, this legislative act has been drawn with a view to protecting one of the most sacred and intimate moments of Christian life when the faithful, inspired by holy grace, open their hearts during confession so as to reconcile with God and the Church. Yet even if a penitent made confession inappropriate or sacrilegious, for example, abandoning all remorse or not obtaining absolution, a confessor is still obliged to keep in secret everything what he heard during confession. Sigillum is to safeguard not only a penitent but the Sacrament of Penance itself for a repentant cannot discharge a confessor of the duty of preserving secrecy.

${ }^{64}$ Cf. CIC/1983, can. 1323, n. 4; 1324 §1, n. 5. 
According to the doctrine, there is a distinction between primary and ancillary subjects of sigillum. The primary subject of sigillum sacramentale is constituted of all sins, of a penitent himself and others which have been learnt about from the same confession, both mortal and lesser (venial), both secret and public since they have been disclosed in order to obtain absolution, which, by the sacramental power, have become known to a confessor. The ancillary subject comprises circumstances which accompany a sin, names and sins of probable accomplices.

A direct betrayal of sigiullum sacramentale occurs when a confessor reveals the content, that is, the subject of confession (sigillum sacramentale) and when he indicates a penitent. It is not necessary that a penitent knows a person or persons to whom sigillum has been disclosed, but it suffices when a person who has confessed sins is clearly designated: for example, a mayor of a specific city has committed such and such a sin. Sigillum is betrayed also in the event when a person to whom a confessor discloses it is not aware of the fact that it was the subject of confession.

An indirect betrayal of sigillum occurs when, besides the subject, a confessor discloses particular circumstances which have been learnt during confession, thanks to which it is possible to trace or suspect a penitent. This kind of violating sigillum is usually the effect of carelessness of a confessor, mostly unintentional, or it occurs when a confessor is questioned by others who have bad intentions.

A guilty party of a delict is a confessor, that is, a priest or a bishop, who heard confession. If the above mentioned confessors heard confessions invalidly, as unauthorized to do it, they are still obligated to observe secrecy of sacramental confession. If such be the case their actions are regarded as offences of the two categories: delict of can. $1378 \S 2$, n. 2 and violation of sigillum. If a confessor is not a priest, a sigillum, in its strict sense is not betrayed, however, secrecy is violated, as specified in can. 1388 and the offence of $1378 \S 2$, n. 2 occurs.

It should also be emphasized that an offence to be committed requires an intentional guilt on the part of a confessor. And if the delict has been committed intentionally, violation of sigillum, both direct and 
indirect, consists in a definite intention of a priest to break the law; wherefore no offence occurs if disclosure of confession is the result of carelessness or negligence as there is lack of clear intention of breaking the law. Such being the case, a delict in effect of an unintentional guilt may be pronounced, as prescribed in can. 1389 §2. In view of the above, it is always advisory to remind priests of keeping any information heard during confession, however harmless it may seem, in secret.

\subsection{Penal sanctions}

Canon $1388 \S 1$ prescribes various penalties for violation of sacramental seal, whether direct or indirect. Direct betrayal is punishable with latae sententiae excommunication reserved to the Apostolic See, namely, the Apostolic Penitentiary for internal scope of affairs (cf. Pastor Bonus, articles 117 and 118) and the Congregation for the Doctrine of Faith dealing with the external scope (cf. Pastor Bonus, art. 52). In the case of indirect violation of sacramental seal an offender is by no means able to justify his actions (cf. can. $1324 \S 1, \mathrm{n} .5$ ), thus he incurs the penalty of excommunication. It is so because indirect violation of sacramental seal is inexcusable, whether with violence, death threats or saving the nation since, as explicitly prescribed by can. 983 , sacramental seal is inviolable.

For indirect violating the confessional seal an offender may incur the penalty of ferendae sententiae which is indefinite but compulsory.

\subsection{Indications regarding the remission of penalty}

A request for exemption from the penalty of excommunication regarding the indirect violation of sacramental seal, addressed to the Apostolic See, must include the following data: age (at least approximate) of a penitent; date of committing an offence; number of times a delict has been committed; the circumstances of the delict; has the offence been committed voluntarily (in effect of intentional guilt - dolus) or in consequence of carelessness and negligence (in effect of unintentional guilt - culpa); has the penitent as the object of betrayal incurred any damages; were there witnesses of a betrayal and did 
they know that violation of sigillum sacramentale had been done, and was this the cause of depravation; is the offender a confessor who has normally observed sigillum sacramentale; is the offender rational or over-rigorous $^{65}$.

It is crucially important in the case of violating sigillum sacramentale whether it has been committed consciously and voluntarily, that is, as an intentional guilt or in effect of culpable negligence, that is, unintentional guilt. And it is the first offence which is reserved to the Apostolic See. When prosecuting the case it is essential to assess whether a confessor has remorse or not; does anyone else know about violation of sacramental seal (clerics, seculars, trustworthy persons, has it been discussed); hat the penitent whom the betrayal concern incurred any kind of damage, moral, spiritual or material. Finally, the information which might be helpful is the one concerning the confessor himself: how has he usually behaved on the matter of the Sacrament of Penance and the sacramental seal - has he acted with required discretion or not ${ }^{66}$.

\section{An attempt to ordain a woman to the priesthood}

\subsection{Essential features of a delict}

The Norms De delictis reservatis of 2010 reserve to the Congregation for the Doctrine of Faith, among other things, delictum gravius attentatae sacrae ordinationis mulieris, that is, a delict of attempted priestly ordination of women ${ }^{67}$. There is no corresponding prescript, either in the Code of Canon Law of 1983 or The Code of Canons of the Eastern Churches of 1990, nor in the Norms of De gravioribus delictis of 2001. The delict in question was defined by the Congregation for the Doctrine of Faith only in $2007^{68}$.

The offence in question is closely associated with Morulo Antonio Braschi, founder of a schismatic community, who had made an

${ }^{65}$ C.E. Commentz, Quando e come..., 21.

${ }^{66}$ Cf. W.H. WoestMen, Ecclesiastical sanctions..., 262.

${ }^{67}$ Congregatio pro Doctrina Fidei, Normae de delictis..., 423-424.

${ }^{68} \mathrm{Cf}$. Congregatio pro Doctrina Fidei, Decretum generale de delicto attentatae sacrae ordinationis mulieris, AAS 100(2008), 403. 
attempt of ordaining women. The Congregation for the Doctrine of Faith, which intervened in that case, issued the Declaration Monitum on 29 June $2002^{69}$, to be followed by the Decree of excommunication of 5 August $2002^{70}$ and the Decree of 21 December $2002^{71}$.

With a view to protecting the nature and validity of the Sacrament of Holy Orders, the Congregation for the Doctrine of Faith, empowered by the highest Church authority (cf. can. 30 of CIC/1983), during the Ordinary Session of 19 December 2007, decided that, pursuant to the prescript of can. 1378 of the Code of Canon Law, both a delinquent who had attempted to confer upon a woman sacred ordination and a woman who had attempted to receive sacred ordination, incurred the penalty of latae sententiae excommunication, reserved to the Apostolic See. In the event that a person who attempted to ordain a woman or a woman who attempted to receive ordination, are the followers of an Eastern Church and subjects to the Code of Canons of the Eastern

${ }^{69}$ According to the Declaration, the priestly ordination in question was a simulation of the Sacrament and therefore was null and invalid as well as constituting a serious offense to the divine constitution of the Church. It is also the serious offence against the unity of the Church as a consecrating bishop belongs to a schismatic community. Moreover, pursuant to can. $1347 \S 1$ of CIC/1983, the Congregation admonished the women who had received the holy orders and appealed to them to nullify the ordination. Not complying to the order of nullity of simulated priestly ordination within the time limit of 22 July 2002 was to result in imposition of excommunication (ferendae sententiae) reserved to the Apostolic See, Congregazione per la Dottrina della Fede, Dichiarazione (Monitum), (L'Osservatore Romano, 11 luglio 2002), 6.

${ }^{70}$ By virtue of her Decree of 5 August 2002, the Congregation for the Doctrine of Faith, incurred upon the women who had attempted to receive the holy orders and despite admonition had not nullified the ordination, nor asked for forgiveness for caused depravation, the penalty of excommunication (ferendae sententiae) reserved to the Apostolic See, cf. Z. SuCHECKI, Le privazioni e le proibizioni..., 74.

${ }^{71}$ The Congregation for the Doctrine of Faith, by virtue of the Decree of 21 December 2002, rejected, both a request for revocation of the excommunication decree of 14 August 2002 and the recourse of 27 September 2002. In the said case the recourse was not possible as it concerned a decree of excommunication issued by a Dicastery of the Holy See acting in the name of the Supreme Pontiff (cf. canon 360 of CIC/1983). Accordingly, the Congregation upheld the decree of excommunication of 5 August 2002, cf. Congregazione Per la Dottrina della Fede, Decreto (L'Osservatore Romano, 27-28 gennaio 2003), 8 . 
Churches, pursuant to the prescript of can. 1443 of this Code, are liable to major excommunication, the remission of which is reserved to the Apostolic See (cf. can. 1423 CCEO/1990). The above regulations came into force with the date of publication in the L'Osservatore Romano daily newspaper ${ }^{72}$. The prescriptions of the quoted decree were included in the Norms of 2010 issued with an appendix on the penalty of dismissal or deposition of a cleric.

A delict of attempting to incur sacred ordination on a woman is first of all violation of a doctrinal character. Such an act becomes a formal and an outright repudiation of the doctrine which the Church has always taught and which was explicitly stated by John Paul II in his Apostolic Letter Ordinatio Sacerdotalis in 1994: "The Church does not consider herself authorized to admit women to priestly ordinatio$\mathrm{n}^{\text {"73 }}$. According to the above decree this statement should be considered final and binding by all the followers of the Church. Denying this doctrine should be regarded as repudiation of the truth of the Catholic faith, implicating the necessity of imposing a suitable penalty, according to cann. $750 \S 2$ and 1371, n. 1of CIC/ $1983^{74}$. Furthermore, as specified by the Congregation for the Doctrine of Faith in her Decree of 21 December 2002, the persons who reject the above doctrine claim that the Pontifical Magisterium might be binding only when based on a decision of the College of Bishops, supported by the sensus fidelium and approved by the major theologians. Such an interpretation stands in opposition to the dogma of the Pontifical Magisterium, affirmed by the Vatican Councils I and II, and implies the rejection of irreformability of the Pontifical teaching of the doctrine, the latter of which should be definitely followed by the faithful ${ }^{75}$.

\footnotetext{
${ }^{72}$ Congregatio pro Doctrina Fidei, Decretum generale de delicto attentatae sacrae ordinationis mulieris, (19 dicembris 2007), AAS 100(2008), 403.

${ }^{73}$ John PaUl II, The Apostolic Letter Ordinatio sacerdotalis, n. 4, 22 May 1994 (L'Osservatore Romano, 30-31 maj 1994), 7-9

${ }^{74}$ Cf. John Paul II, The Apostolic Letter motu proprio Ad tuendam fidem, n. 4 (L'Osservatore Romano, 18 maj 1998), 13-15.

${ }^{75}$ Cf. Congregazione Per la Dottrina della Fede, Decreto (L'Osservatore Romano, 27-28 gennaio 2003), 8; cf. D. Ciтo, Delicta graviora..., 51-52.
} 
The offenders of the described delict are both, a person who attempts to ordain a woman and a woman or women who attempt to receive sacred ordination ${ }^{76}$. The apostates who try to confer holy orders may be clerics, deacons, presbyters, bishops, but also seculars, men or women. Regardless of whether the ordination has been conferred on a woman by a validly consecrated bishop or another person, it is still regarded as attempted. It is so because according to can. 1024 of the Code of Canon Law of 1983 the ordination to the priesthood is valid only if an ordinand is vir baptizatus. The penal liability is the same for all participants of a delict, thus it is uniformly to latae sententiae excommunication reserved to the Apostolic See in the case of the followers of the Roman Catholic Church, and to major excommunication for the followers of the Eastern Churches, also reserved to the Apostolic Church. Moreover, if an offender is a cleric, he incurs an additional expiatory penalty of dismissal or deposition. Heavier liability of a cleric derives from particular harmfulness of the discussed offence committed by him ${ }^{77}$.

\subsection{Penal sanction}

For the delict of attempting to ordain a woman to the priesthood the Norms of 2010 prescribe the latae sententiae excommunication reserved to the Apostolic See and, as regards a cleric, a facultative penalty of dismissal or deposition ${ }^{78}$. The same penalty, also reserved to the Apostolic See, has been prescribed in the decree of the Congregation for the Doctrine of faith in 2007.

\footnotetext{
${ }^{76}$ Cf. D.G. Astigueta, Ultime modifiche al motu proprio..., 79.

${ }^{77}$ D. Cito, Delicta graviora..., 51.

${ }^{78}$ Art. 5: "n. 1 firmo praescripto can. 1378 Codicis Iuris Canonici, tum qui sacrum ordinem conferre attentaverit tum mulier quae sacrum ordinem recipere attentaverit in excommunicationem latae sententiae Sedi Apostolacae reservatam incurrit" (...) ,3 si vero reus sit clericus dimissione vel depositione puniri peterit", Congregatio PRO Doctrina FIDEI, Normae de delictis..., 423.
} 


\subsection{Indications regarding the remission of penalty}

Due to the fact that in order to commit the above delict all conditions must be fulfilled, both subjective and objective, it seems practically improbable that such an offence might be pronounced. It is an offence which is rather of rare occurrence.

\section{Conclusion}

Pursuant to the prescriptions of $\S 3$ of can. 1354, the Apostolic See can reserve the right to remit penalties. Reservation specified in the penal law, in its general sense, denotes revoking the right to exempt from penalties by lower superiors and granting this right exclusively to higher ones. Wherefore, the reserved penalties may be remitted solely by the Apostolic See and the entities authorized by her. If a penalty is reserved to the Apostolic See, in ordinary cases it is her exclusively who is empowered to exempt from this penalty, unless the law explicitly entitles other persons or the Apostolic See authorizes them by herself.

In accordance with the currently applicable canon law, there are only six delicts liable to latae sententiae excommunication the remission of which is reserved to the Apostolic See. They are: profanation of consecrated species (can. 1367); physical assault upon the Roman Pontiff (can. $1370 \S 1$ ); absolution of an accomplice in a sin against the sixth commandment of the Decalogue (1378 §1); consecration of a bishop without a pontifical mandate (can. 1382); direct violation of sacramental seal (can. $1388 \S 1$ ); an attempt to ordain a woman to the priesthood (General Decree of the Congregation for the Doctrine of Faith of 19 Dec 2007). In the above cases any appeals should be lodged at the proper Dicastery of the Roman Curia. It should be noticed that each case ought to be prosecuted carefully so as to confirm whether the penalty of excommunication, reserved to the Apostolic See, has actually been incurred. Therefore each examination will require indispensable knowledge of essential features of a delict subject to penalty, the remission of which is reserved to the Apostolic See. 


\section{Summary}

The article titled The Canonical Delicts Liable to Penal Sanctions Reserved to the Apostolic See analyses the consecutive offences under the penalty of latae sententiae excommunication the remission of which is reserved to the Apostolic See. According to the currently applicable canon law, there are only six delicts liable to latae sententiae excommunication the exemption form which is reserved to the Apostolic See. They are: profanation of consecrated species; physical assault upon the Roman Pontiff; absolution of an accomplice in a sin against the sixth commandment of the Decalogue; consecration of a bishop without a pontifical mandate; direct violation of sacramental seal; an attempt to ordain a woman to the priesthood. The knowledge of essential features of these offences seem particularly important in re-examining the case and resolving whether the penalty of excommunication, reserved to the Apostolic See, has actually been incurred.

KEY wORDS: Reservation of penalties, remissions of penalties, canonical delicts

SŁowA KLUCZOWE: zastrzeżenie kar, zwalnianie z kar, przestępstwa kanoniczne 